\title{
A Global History of Asian's Presence In Kisumu District of Kenya's Nyanza Province
}

\section{Gordon Onyango Omenya}

\section{(2) OpenEdition \\ Journals}

Electronic version

URL: https://journals.openedition.org/eastafrica/329

DOI: $10.4000 /$ eastafrica.329

ISSN: 2790-1076

\section{Publisher}

IFRA - Institut Français de Recherche en Afrique

\section{Printed version}

Date of publication: 1 March 2016

Number of pages: 179-207

ISSN: 2071-7245

\section{Electronic reference}

Gordon Onyango Omenya, "A Global History of Asian's Presence In Kisumu District of Kenya's Nyanza Province", Les Cahiers d'Afrique de l'Est / The East African Review [Online], 51 | 2016, Online since 07 May 2019, connection on 09 December 2021. URL: http://journals.openedition.org/eastafrica/329 ; DOI: https://doi.org/10.4000/eastafrica.329 


\section{A Global History of Asian's Presence In Kisumu District of Kenya's Nyanza \\ Province}

\section{Gordon Onyango Omenya}

\section{Introduction}

The idea of globalization and global history is not a recent phenomenon. As early as the first century, East African Coast had already started witnessing the emergence of traders from Asia especially the Chinese who brought porcelain and other trade items along the coast of East Africa. Towards the end of the $18^{\text {th }}$ Century and the beginning of the $19^{\text {th }}$ Century, globalization took a new dimension due to imperialism and colonialism. These two processes opened up the world and more so East Africa to the rest of the world. The Africans were thus exposed to new forms of religion and their economy was opened up to the international market system and economy. These activities as well as slave trade laid the foundation upon which global history was to be written. In Kenya for instance, the colonial administration's 'encouragement' of trade was undertaken within a broad economic policy framework which assigned the different races in Kenya and fractions of merchant capital specific roles. Occupying the highest rank on the commercial ladder were European importers and exporters. Asians occupied a middle position while Africans formed the lowest chain in the marketing system. The colonial government also employed indirect and direct compulsion to 'encourage' trade. For instance, in addition to raising revenue, the imposition of the hut tax early in 1902, was also intended to induce Africans to grow and sell surplus produce if they were to be able to meet the tax obligation. ${ }^{1}$ In such situations, Africans were compelled to engage in exchange of goods in Kisumu, Ndere, Yala and Kendu Bay with the Asians so as to raise money to pay for their tax.

The Indian Question in Kenya in general, was a creation of colonialism. Herzig ${ }^{2}$ observes that during the last decades, the Asians in Kenya have passed through several stages of migration, which can be taken exemplarily for different approaches. During the early years, they were a typical labour diaspora due to the indentured workers. With the increase of passenger migration, they established themselves as middleman minority or a trading diaspora. Later, with increasing globalization, the Kenya Asians became a transnational community in addition to the diaspora. Older forms have not disappeared but decreased while new forms have emerged. This means that still some parts of the Kenya Asians represent the typical type of petty trader with family members and relatives as unpaid labourers. Due to the impacts of globalization, transnational activities like travel or communication have increased after Kenya received her independence. Therefore, some Kenyan Asians started to live a transnational life- however, not all.

\footnotetext{
${ }^{1}$ P. Ndege, Internal Trade in Kenya 1895-1963. In Ochieng W, and Maxon R, (ed) An Economic History of Kenya (Nairobi: East African Educational Publishers, 1992) p.204.

${ }^{2}$ P. Herzig, South Asians in Kenya: Gender, Generation and Changing Identities in Diaspora (Munster: LIT Verlag / Transaction publishers, 2006) p.60.
} 
And in contrast to other transnational communities, the East African Asians are connected not only with their place of origin but also with Europe and North America. The concept of Indian diaspora and Asians is thus used exchangeably to help in the reconstruction of the global history of Afro-Asian relations in Kenya's Kisumu district, of Kenya's Nyanza province. The fundamental questions in this paper are: what are the Afro-Asian socio-economic contestations in Kisumu district, how did the Asians influence the urban landscape of Kisumu and what are the levels of Afro-Asian interaction in Kisumu district. The major theme in this paper is the issue of race and globalization and how the two have both influenced the urban landscape and relations between Asians and African in Kisumu district of Nyanza province.

The Indian diaspora in Kenya is a microcosm of India and no other diaspora has such a global spread and diversity. ${ }^{3}$ Though they have multiple diversities, all of them have identity of being ethnic Indians. ${ }^{4}$ The origins of the modern Asian population of East Africa can be traced back to roughly the middle of the nineteenth century, although there has been a historical commercial connection between East African coast and the western seaboard of India since about the second century A.D. ${ }^{5}$ Early contacts between Indian traders and East Africa that go back over centuries were however sporadic. But, the major influx of Indians in East Africa came with colonization when they were brought in as indentured labourers to build the railway from Mombasa at the coast to Uganda. ${ }^{6}$

It should be noted that the Asian community, being a conglomeration of many diverse communities, languages, religions and customs is not a monolithic community with a cohesive leadership. ${ }^{7}$ The internal character of the Kenyan Asian community was such that the many religious divisions meant that there was no dominant leader or authoritative institution that could speak for everyone.

Indian settlement in Kenya generally and in Kisumu district of Nyanza province was a colonial venture to entrench colonial administration and capitalism into the interior parts of Nyanza. This was achieved, first by the construction of the Kenya- Uganda railway, which was completed in 1901. Kisumu, by then was administratively in Uganda as per the colonial boundaries. In Nyanza province, Asian settlement followed a pattern of a settlement scheme, which was sanctioned by the colonial government which saw the establishment of the first authorized and formal Asian settlement scheme in Kibos and later on in the Nyando valley within Kisumu district. ${ }^{8}$

\footnotetext{
${ }^{3}$ J.C. Sharma, The Indian Communities in Overseas Territories of France: Problems of Identity and Culture. In Jayaram, N (ed) Diversities in The Indian Diaspora: Nature, Implications, Response (New Delhi: Oxford University Press, 2011) p. 124.

${ }^{4}$ A. Dubey, India and Indian Diaspora in Africa: Diversity and Challenges. In Dubey A, (ed) Indian Diaspora in Africa: A Comparative Perspective, (New Delhi: MD Publication PVT Ltd, 2010) p.19.

${ }^{5}$ J.A. Mangat, History of Asians in East Africa C 1886- 1945 (New York: Oxford University Press, 1969) p. 467.

${ }^{6}$ Y.Tandon, The Future of the Asians in East Africa (London: Rex Collings Ltd, 1973).

${ }^{7}$ P. Zarina, I am A Kenyan South Asian (Nairobi: Awaaz 2004) p.42.

${ }^{8} \mathrm{G}$. Omenya, The Relations Between Asian and African Communities: A Comparative Study of Western and Nyanza Provinces 180 of Kenya, 1900-2002 (PhD Thesis l'Universite de Pau, France, 2015).
} 
Upon the terminal of the railway at the lakeshore of Kisumu, there were two types of shelter, which provided for both public and domestic architecture. These were tents and sheet iron buildings that were introduced by the Uganda railways and the Colonial Administration and used for all manner of functions. The architecture derived from manipulations, the sheet iron as walls and roofs was gradually eliminated in Kisumu with the special development conditions attached to the leases of alienated Crown Land from around 1930. Some of those sheet iron business and residential premises have survived into the postcolonial period up to date. ${ }^{14}$

The Second World War slowed down the growth of Kisumu, resulting in a tremendous demand for Asian housing, business premises and factory sites. The greater demand was in the Asian sector because at the time urban real estate investments were essentially an economic relationship between Kisumu's Europeans and Asians and excluded Africans. Most significant for Kisumu was the opening of the National Bank of India branch office in Kisumu in April $1913^{15}$ (Figure 1).

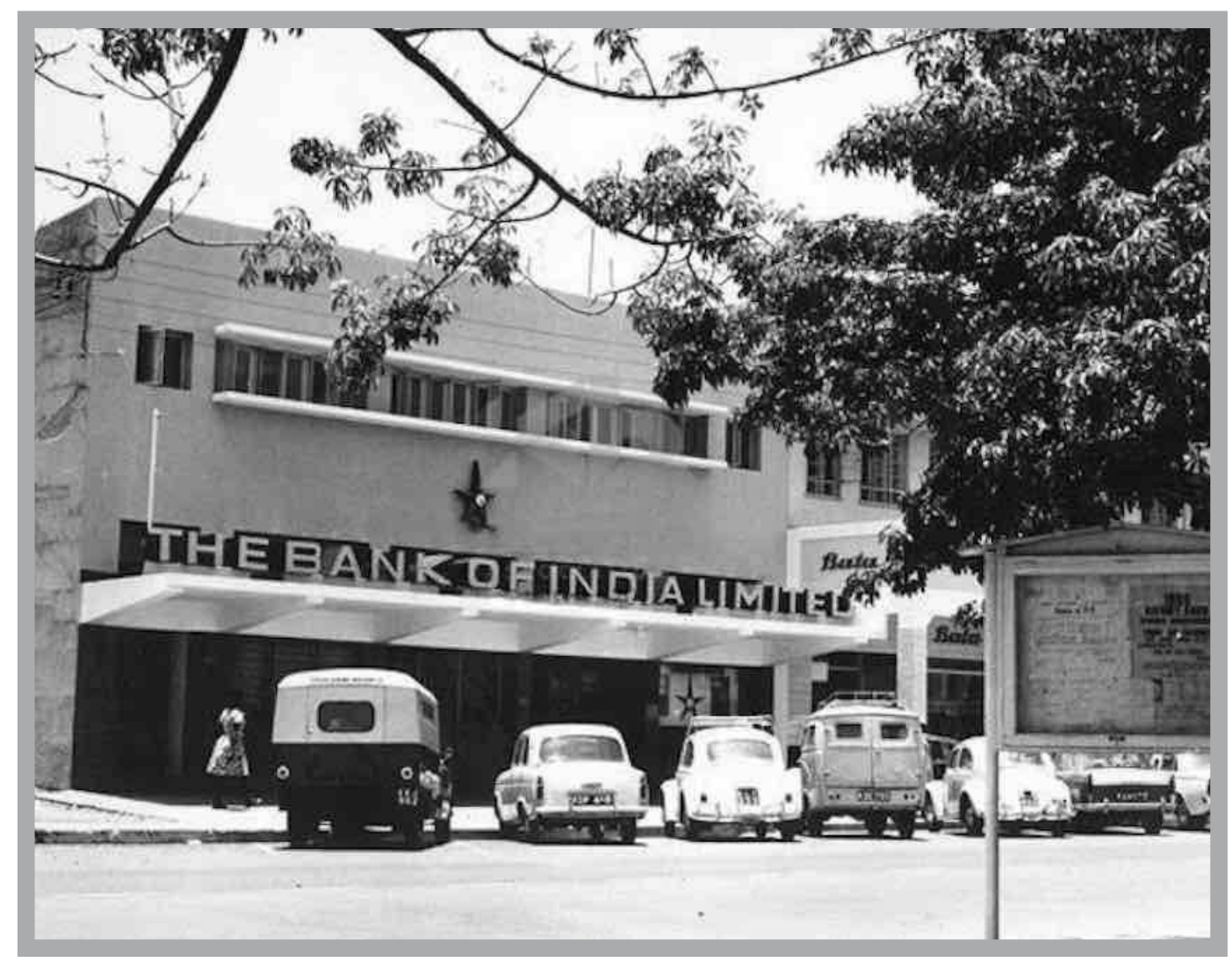

Fig 1. A picture of bank of India established in Kisumu as early as 1913 Source: ismailmail.files.wordpress.

\footnotetext{
${ }^{14}$ G.Anyumba, Kisumu Town: History of The Built Form, Planning and Environment 1890- 1990 (Ph.D. Thesis, Moi University, 1995).

${ }^{15}$ Anyumba, Kisumu Town.
} 


\section{Asian Influence in Kisumu's Built Form}

The advent of British rule in India brought to an end traditional state patronage of architecture. The impact of European aesthetics would result in a new synthesis and meaning in architecture ${ }^{16}$. This new architectural form; classical and Gothic motifs en vogue in London was fostered by the (Indian) state. Later at the beginning of the $20^{\text {th }} \mathrm{C}$ indigenous traditions were mixed with foreign ones. Thus in the diaspora Hindu of Kisumu, we see a culture with a lengthy history of articulated aesthetics sensibilities concordant with his culture.

The built form and environments of Kisumu were divisible into three distinct physical morphologies; the old town, the peri-urban areas and rural Kisumu. The built form, the environment and its associated landscapes are a summation of the impacts of the Asiatic and colonial culture on the urban structure of Kisumu. The old town was conceived of as the exclusive preserve of the British. However, a co-occupant of the old town was an assortment of 'intervening group's who were segregated from the British from the onset. The Asian community, who formed the largest of the group left an oriental imprint on the environment of Kisumu.

The landscape has been one of two successive 'Indian bazaars', Islamic and Khoja mosques, a variety of temples (Figure 2), the ubiquitous shop cum residence, multifamily tenements, engineering workshops, schools, hostels, hospitals, cemeteries and a crematorium. Covering a large and continuous area of Kisumu, this 'Asian zone' in town was segregated on the basis of specific Indian communities. ${ }^{17}$

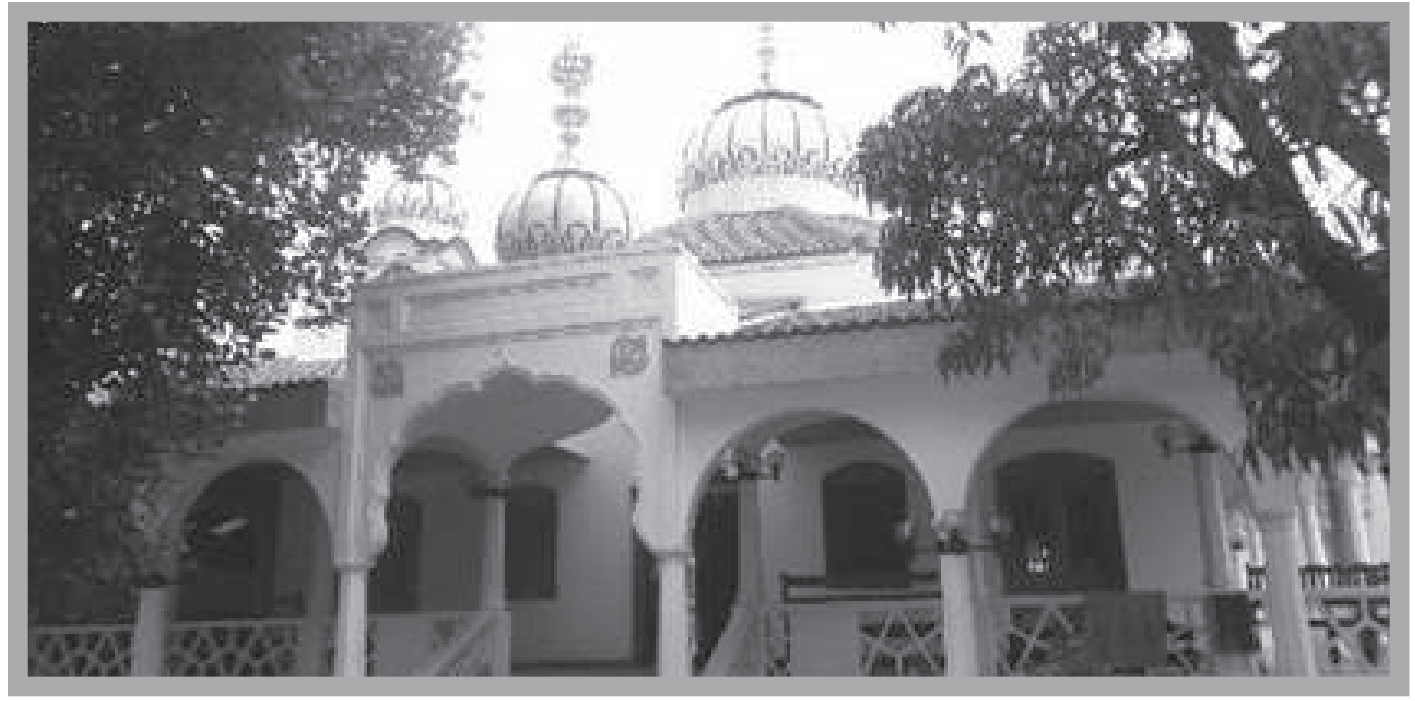

Fig 2: A picture of the Siri Guru Singh Sabha Kisumu (Sikh temple) - foundation stone laid on 21 December 1913. (Daily Nation, 20/12/2013) Source: ismailmail.files.wordpress.

${ }^{16}$ J. Morris, and S. Winchester, Stones of Europe, The Buildings of the Raj (Oxford: Oxford University Press, 1986) p.13.

${ }^{17}$ Anyumba, Kisumu Town, p.5. 
Different sections of Kisumus' urban structures reflected different urban morphologies, which in turn were made up of distinctive architectural styles. These designs were traceable from an earlier pre-railway, colonial period or of the more recent international style. Architecture akin to that of pre-colonial period could be found in rural Kisumu (Figure 3 ), and in parts of the inner peri-urban Kisumu. The shop cum residence of Asians was copied by Africans in the peri-urban and rural areas in Kisumu and in many small towns in Kenya. The 'environment aesthetics' related well to the visual impact of built forms and the environment. ${ }^{18}$

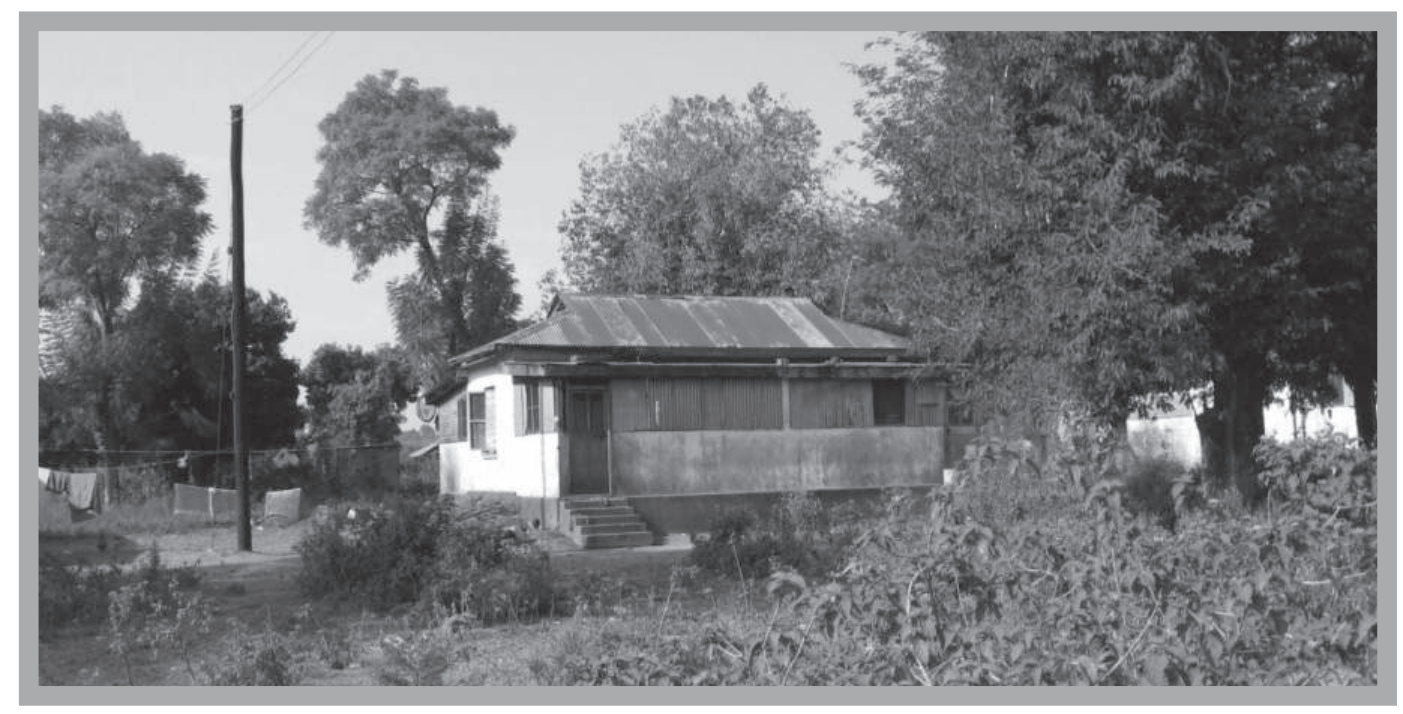

Fig 3: An Indian House in the Rural Village in Kisumu Source: Picture taken by Gordon Omenya

\section{Early Forms of Afro-Asian Socio-Economic Relations}

The idea of globalization and global history is not a recent phenomenon. As early as the first century, East African Coast had already started witnessing the emergence of traders from Asia especially the Chinese who brought porcelain and other trade items along the coast of East Africa. Towards the end of the $18^{\text {th }}$ Century and the beginning of the $19^{\text {th }}$ Century, globalization took a new dimension due to imperialism and colonialism. These two processes opened up the world and more so East Africa to the rest of the world. The Africans were thus exposed to new forms of religion and their economy was opened up to the international market system and economy. These activities as well as slave trade laid the foundation upon which global history was to be written. In Kenya for instance, the colonial administration's 'encouragement' of trade was undertaken within a broad economic policy framework which assigned the different races in Kenya and fractions of merchant capital specific roles. Occupying the highest rank on the commercial ladder were European importers and exporters. Asians occupied a middle position while Africans formed the lowest chain in the marketing system. 
The colonial government also employed indirect and direct compulsion to 'encourage' trade. For instance, in addition to raising revenue, the imposition of the hut tax early in 1902, was also intended to induce Africans to grow and sell surplus produce if they were to be able to meet the tax obligation. ${ }^{19}$ In such situations, Africans were compelled to engage in exchange of goods in Kisumu, Ndere, Yala and Kendu Bay with the Asians so as to raise money to pay for their tax ${ }^{20}$.

As early as 1902, Jamal Hasham an Asian trader stationed in Kisumu, dealt in Amerikani (American) cotton, importing his own brand on which at every yard, his picture was printed. His relationship with the local people in Kisumu was so good and he was well-known for his fair dealing that he acquired the nickname 'Bwana mzuri' (Good man) ${ }^{21}$. This means that in this hybrid arrangement and plural space not everything was conflictual. There were certain things that the Africans had internalized from Asians and vice versa. So the postcolony was not just about conflicts. Atieno Odhiambo ${ }^{22}$ discussing Asian political ambitions in Kenya from 1905-1939 argues that it was as the trader that the Indian presence was to have it's initial and even long term impact among the interior Africans. The Indian that most Africans knew of, was the dukawalla, the shopkeeper in the bush. But the shopkeeper was only an appendage of the Indians in the three main centres Nairobi, Kisumu and Mombasa. The Western building materials such as the popular mabati (corrugated iron sheet) which the Asians sold to the Africans would gradually replace the not permanent thatch for roofing mud walled African homes. The popular highly coloured cotton textiles known as kitenge and kanga, originally imported from Holland, and noted for their appealing Indonesian influential prints became a popular wear for the great majority of African women. The importation and distribution of the fabrics were also to be the work of Asian traders. ${ }^{23}$

At first, Africans were suspicious of exotic ware, but they soon found that the clothes and blankets were warmer and less cumbersome than their traditional wares. Besides clothes and blankets, other merchandise like oil, salt, sugar, tea, basins, lamps among others were introduced to the people of Nyanza for the first time. The Asians also bought certain amounts of skins, cattle, cotton and sisal and all these products were sold to Asians by Africans who in turn distributed them in the country. ${ }^{24}$ What the Asian merchants brought changed the consuming habits of the local inhabitants forever. Their dressing habits began to change as they moved from the wearing of hides and skins to a dutch-manufactured kanga with deep Indonesian influence. Initially, the Nyanza people's reception of these foreign cultures and forms of knowledge seemed ambivalent but later, they embraced them. Nevertheless, in Bhabha's ${ }^{25}$ argument, cultural production is most productive when it is also most ambivalent, and indeed, the Africans fully embraced exotic wares brought by the Asians at the expense of their traditional wares.

\footnotetext{
${ }^{19}$ Ndege, Internal Trade in Kenya, p. 204.

${ }^{20}$ G. Omenya, The Relations Between The African And Asian Communities Of Kenya's Nyanza Region, 1901 - 2002 (M.A

Thesis, Kenyatta University, 2010).

${ }^{21}$ C. Salvadori, We Came in Dhows Vol 1-3 (Nairobi : Paperchase Limited, 1996) p.149.

${ }^{22}$ O. Atieno, Siasa: Politics and Nationalism in East Africa 1905 - 1939 (Nairobi: Kenya Literature Bureau, 1981).

${ }^{23}$ A. Seidenberg, Mercantile Adventures: The World of East African Asians 1750-1985 (New Delhi: New Age International (P) Limited Publishers, 1996) p.47.

$184{ }^{24}$ W. Ochieng', An Outline History of Nyanza Up to 1914 (Nairobi: East African Literature Bureau, 1974) p.86.

${ }^{25}$ H. Bhabha, The Location of Culture (London: Routledge, 1994).
} 
Postcolonial thinking is thus not to go back to the past and discard everything European or Asian but to dismantle those values and institutions that perpetuate our marginalization. Indeed some values and institutions were positive.

In 1903, the township boundaries were gazetted and some 12,000 acres, including water, set aside for its development. The new township reverted to its original name, Kisumu, in substitution of Port Florence. At this time, there was an 'Old Kisumu', that consisted of two rows of Stalls on Mumias Road, north of the Gulf. It was later demolished in the twenties when new plots became available on Odera and Ogada Streets in the present day Kisumu, hence the new area acquired the name 'New Bazaar'. ${ }^{26}$

Between 1910 and 1920, Kisumu was an important commercial centre. It was a major axis where goods imported from outside British East Africa and destined for Nyanza Province could be taxed (KNA, PC/NZA/1/4, 1908/9. ${ }^{27}$ For the Asians, Kisumu was a depot for the distribution of imported goods throughout Nyanza Province and Eastern Uganda. It was also the place where raw materials gathered from African periodic rural markets in the hinterland by the Asians were assembled for export to places like Marseilles, Somaliland and Arabia.

These collections and distribution functions attracted more Africans to reside in the town and in the peri-urban areas. It also enhanced their relations with the Asians (KNA, PC/ NZA Annual Report, 1928). ${ }^{28}$ Trade was on the increase and this led to the expansion of trade at various centres such as Yala, Kendu Bay and Ndere among others. However, racial segregation in towns, unequal business opportunities and taxation, import and export trade (involving both exotic and local produce) as well as colonial industries like the cotton industry, all these promoted the growth and expansion of British imperialism.

The enterprises of some of the pioneer Indian traders in the interior expanded on the foundations laid in the early years. The most notable in this respect were the achievements of Allidina Visram, who built up an extensive East African wide business network. Allidina Visram, an Indian Ismaili operated dukas (shops) in Kisumu (Figure 4) and other posts well before the Uganda Railway was completed. The pattern of commerce adopted in the interior by Visram and the other Asian traders revolved largely around the exchange of an increasing variety of imported goods such as cloth, wire, glassware and lamps for local produce of every description. ${ }^{29}$

Allidina also diversified his business interests to include oil mills at Kisumu obtaining oil from sesame and copra. ${ }^{30}$ Various contemporary accounts describe the expansion of his $d u k a$-based enterprise in different parts of the colony such as Kisumu, Yala among other areas. $^{31}$

\footnotetext{
${ }^{26}$ Anyumba, Kisumu Town.

${ }^{27}$ Anyumba, Kisumu Town.p.80.

${ }^{28}$ Obudho, Periodic Markets.

${ }^{29}$ Mangat, The Immigrant Communities, p.475.

${ }^{30}$ Ibid, p. 477.

${ }^{31}$ Mangat, History of Asians in East Africa, p. 77.
} 
The Indian bazaar in Kisumu, established from the early days of the colonial period, grew in importance as a local centre of Indian trade (KNA, PC \NZA1 $\backslash 2$, AR 1910 \14). In a 1915 report, that included a reference to trade at Yala near Kisumu Simpson, the expert advisor of the Colonial Office averred ${ }^{32}$ :

Yala is the great collecting centre for the grain and produce of the country north of the Yala River. To this station, the natives bring their baskets of grain and sell it to the Indians, who store it ... until it is convenient to send it in bags or carts to Kisumu. The road between Yala and Kisumu is thronged with carts passing to and fro. Those from Yala are loaded, according to the season of the year, with sim sim, maize, beans, hides and skin and those from Kisumu with rice.... Clothes etc'

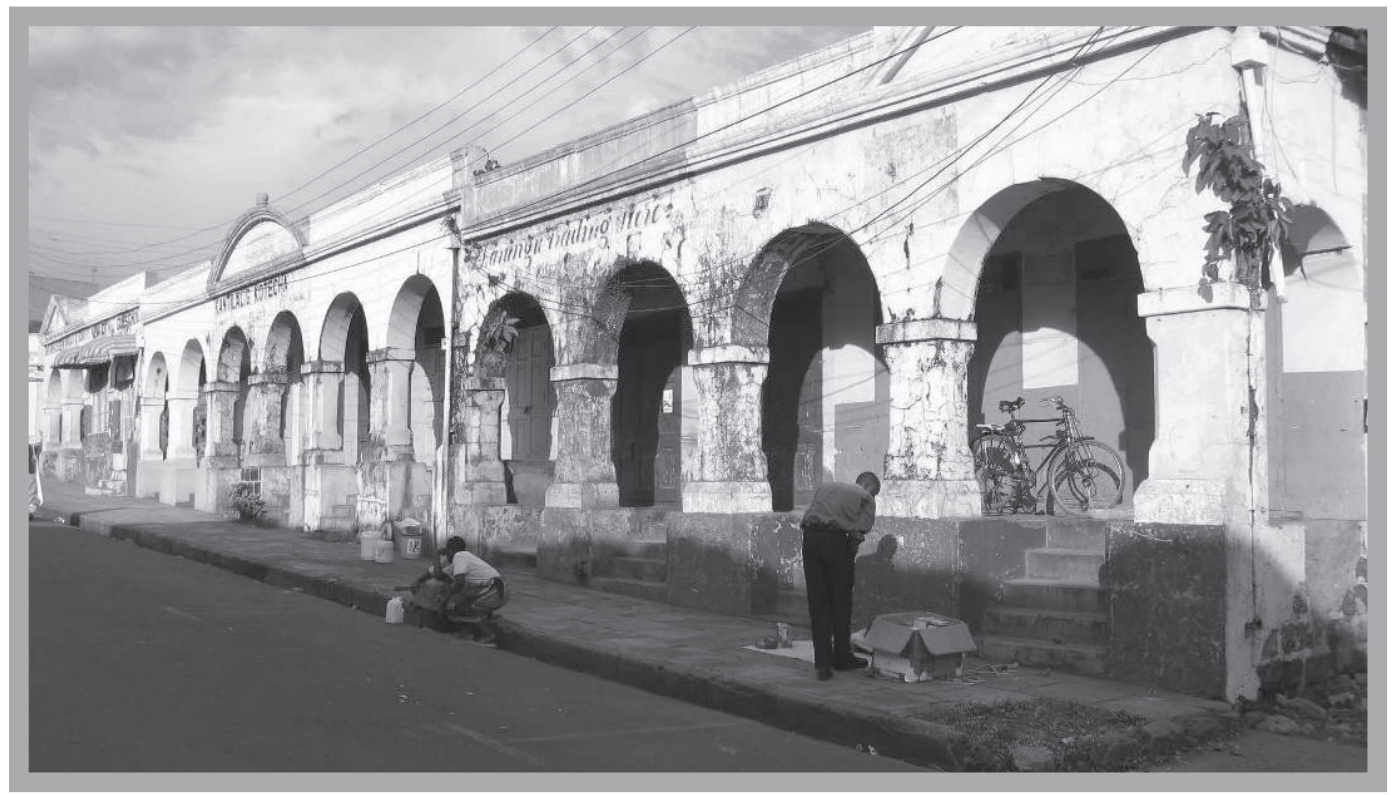

Fig 4: A Classical Building With Asian Architectural Design Showing Asian Shop cum residence in Kisumu Source: ismailmail.files.wordpress.

Afro-Asian relations in Nyanza Province were not centred on trade in food items alone. Many of the skilled immigrants such as Rehmat Khan, Hayer Bishan Singh in Kisumu, Abdul Kassam, among others, were to launch a variety of business enterprises as contractors, outfitters, builders and mechanics. They also helped to supplement the activities of the Indian commercial population, which also witnessed a steady expansion during this period. ${ }^{33}$

With their skills in various fields, Asian artisans imparted to Africans invaluable vocational skills in making furniture, repairing bicycle, printing magazines and books, stocking shops, crafting leather shoes and handbags and teaching so many other income-generating occupations. Through such trainings, there emerged a permanent skilled class of African artisans and technicians within the region and especially in Kisumu.

${ }^{32}$ Ibid, p. 87.

$186{ }^{33}$ Omenya, The Relations Between Asian and African Communities. 
Technologies specific to Kisumu Asian and African cultural groups were distinguishable in the townships pioneer period. The fabrication of technology products of the pre-industrial Indian society was occasioned by the making of Indian carts for local transport work, which by 1913 had become an important business in Kisumu (AR 1913/14). Indian carts on their derivatives were used in virtually all aspects of transportation (Figure 5). Tied to the use of water to power flourmills was another important pre-industrial technology input i.e 'the making of 'gur' the black jiggery from sugar cane. ${ }^{34}$

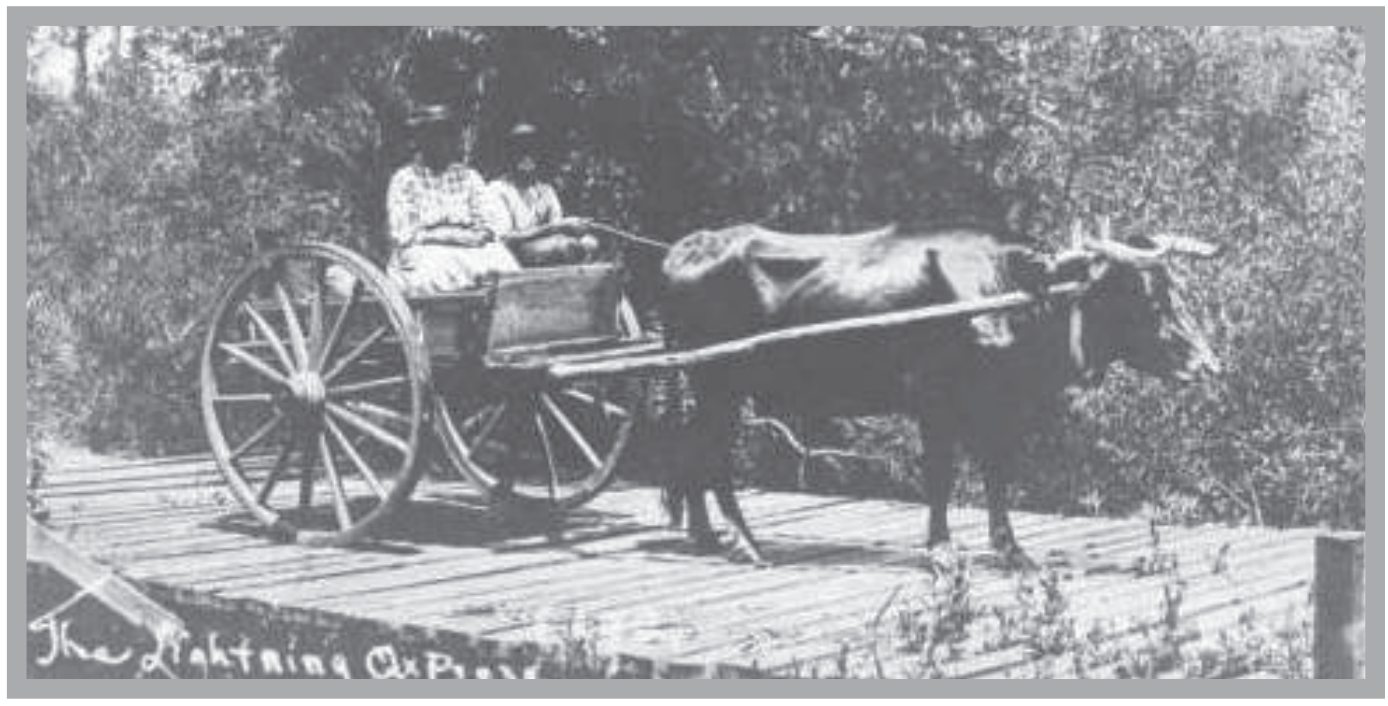

Fig 5: A Picture of an Ox Drawn Cart Source: ismailmail.files.wordpress.

The point to note here is that Afro-Asian political interaction was not achieved during this early colonial period in Kisumu. This is because Asians were not keen on local politics. Their major concern was about settlement in white highlands and recognition of their fundamental rights by the colonial government which culminated into the Devonshire Declaration of 1923 which declared the interest Africans paramount. The Asians were also keen on trade. The issue of segregation was more prominent in the urban parts of Nyanza with Kisumu being more affected. In Kisumu, both Asians and Africans attended separate schools. During the first decade of colonialism, Afro-Asian relations in schools were nonexistent because of the strong segregation policy which rendered Afro-Asian interaction and mixing impossible. ${ }^{35}$

Apart from the government and railway owned residential houses for the Asians in Kisumu, interaction between the Asians and Africans within the residential areas was also minimal. This is because the Asians stayed in isolated and well-fenced residences where Africans could not access.

\footnotetext{
${ }^{34}$ L. Lemmen, Technology Assessment for Projects in Developing Economies: Sugarcane Industry in Western Kenya as A Case Study (Unpublished PhD Dissertation, Eindhoven University of Technology, 1987) p.4.

${ }^{35}$ Omenya, The Relations Between Asian and African Communities.
} 
This fencing of Asian premises was probably a security measure to protect themselves from perceived African attacks, a kind of African protest against their presence in some of these areas. The housing situation in Nyanza and especially Kisumu during the early colonial period 1900-1918, was generally not good since the Asian residences were very crowded. The same condition applied to the Indian landies (residential plots where railway employees and their families lived). A few plots in the Indian bazaar had been taken up by the Indians and new business premises erected. Two Indian residences were in the process of construction. Several other plots which were bought by the Indian community at the sale of plots were not yet developed. This was because of the money market and the high cost of building materials (KNA, PC/NZA/1/16, Annual Report 1920-21). Afro-Asian interaction which took place in the residential areas was therefore between Africans employed by Asians in their houses and also those Africans who went to buy goods from Asian shops which served as their places of work and residence.

The Africans also developed a lot of interest in the Asian jaggery, which they bought and utilized to prepare local gin known as the Nubian gin (African brew). The preparation of Nubian gin was very common in Kibos area. In fact, some Asians also frequented the African settlement houses to take this drink. This was a sign of the emerging inter-racial relations between the Afro-Asian communities. However, this act by the Asians could be

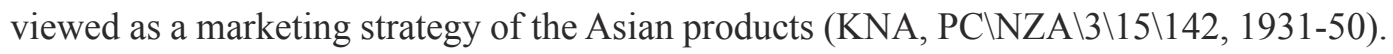

On the consumer side, the activities of the Kavirondo Taxpayers Welfare Association (KTWA), the first African political organization in Nyanza in the 1920s, among other things, stimulated co-operative self-help schemes, particularly in grain milling by waterpower thus competing with the Asians in the processing of local produce. The formation of KTWA thus informed the African protest and resistance to bad trade practices which emerged between the Asians and the Africans on this plural and hybrid postcolonial space of Nyanza.

Conflicts of interest between established Asian businesses and those of new African entrepreneurs also arose. This period also witnessed the expansion in African cash-crop production and the emergence of African small traders in the rural areas. Similarly by 1930s, a class of local African traders in Central and Western Kenya had emerged. Those in Nyanza were particularly opposed to both the magnitude of Asian trade in the reserves and the employment by Asians of African hawkers in trading centres there.

The Kavirondo Chamber of Commerce, an all-African economic pressure group representing the Luo and Luhya African traders, passed several resolutions seeking restrictions on the activities of Asian traders. The Chamber members even suggested separate trading centres for Asians and Africans and also condemned the Local African Council's unpopular practice of allocating plots to Indians in the newly established trading centres against the interest of African traders and designed to keep them in their former place as growers of wimbi (finger millet) and mtama (ordinary millet). The Council was therefore requested to cease inviting Indian traders to trading centres and trade in the prescribed areas be put into 
African hands. ${ }^{36}$

Although there was trade conflict between Asians and Africans on 19 August 1938, a tall Town Clock standing in the middle of the road along the main Oginga Odinga street in Kisumu was unveiled by the then Governor and Commander-in-Chief of Kenya HE Chief Marshall Sir Robert Brooke Pophan. The Town Clock (Figure 6 and 7) was built in memory of Kassim Lakha who arrived in East Africa in 1871 and died in Kampala in 1910. It was erected by his sons Mohamed, Alibhai, Hassan and Rahimtulla Kassim, as the inscription on the Town Clock reads. This change in the urban landscape would later on inform the Afro-Asian socio-economic spaces of interaction.

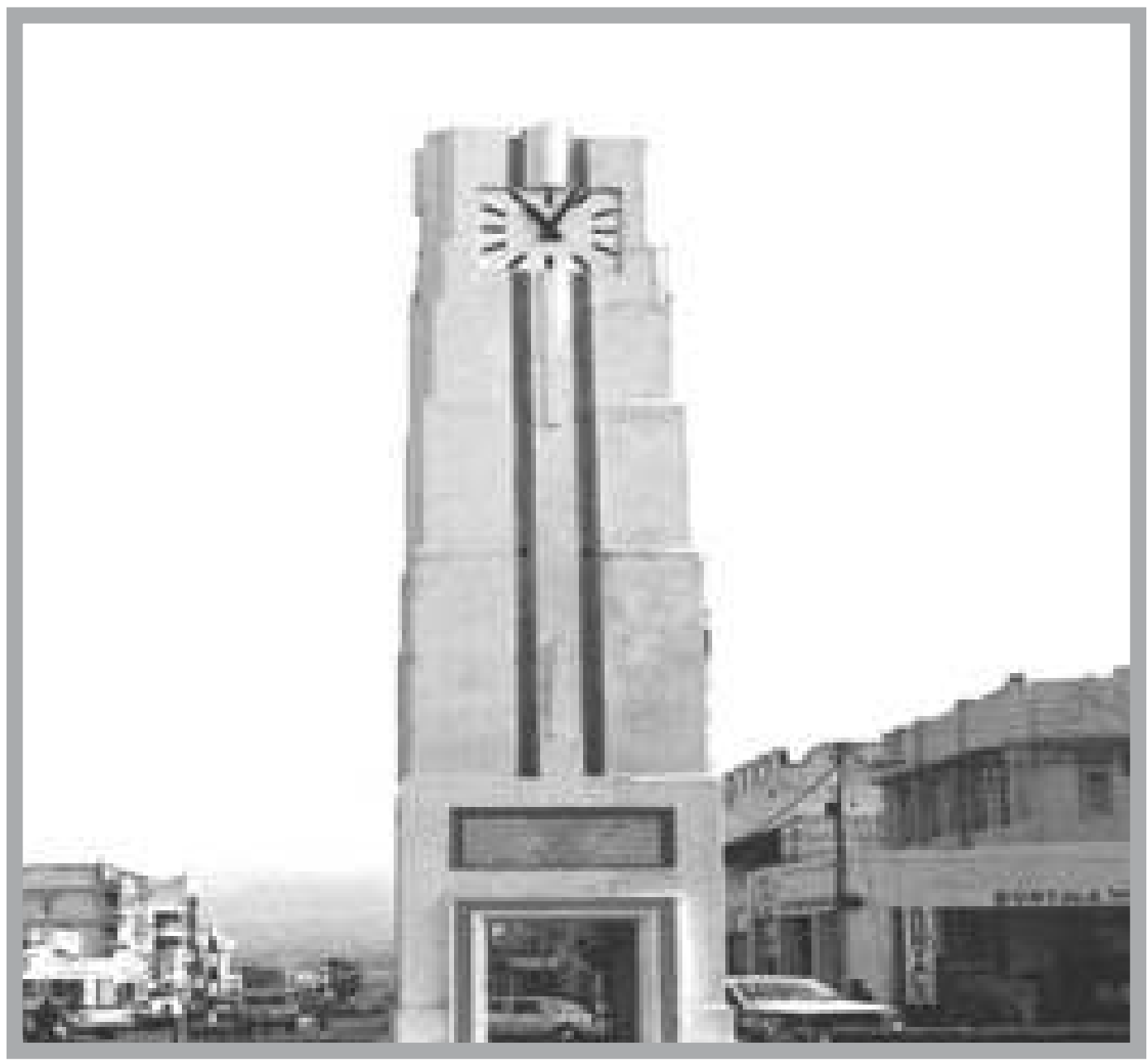

Fig 6: Town Clock (Saa Maduong) in Memory of Kassim Lakha Source: Picture taken by Gordon Omenya (2015).

${ }^{36}$ P. Memon, "Colonial Marketing, and Urban Development in the African Reserves", Journal of Eastern Africa Research and Development, Vol 6, No.2 (1976) p.210. 


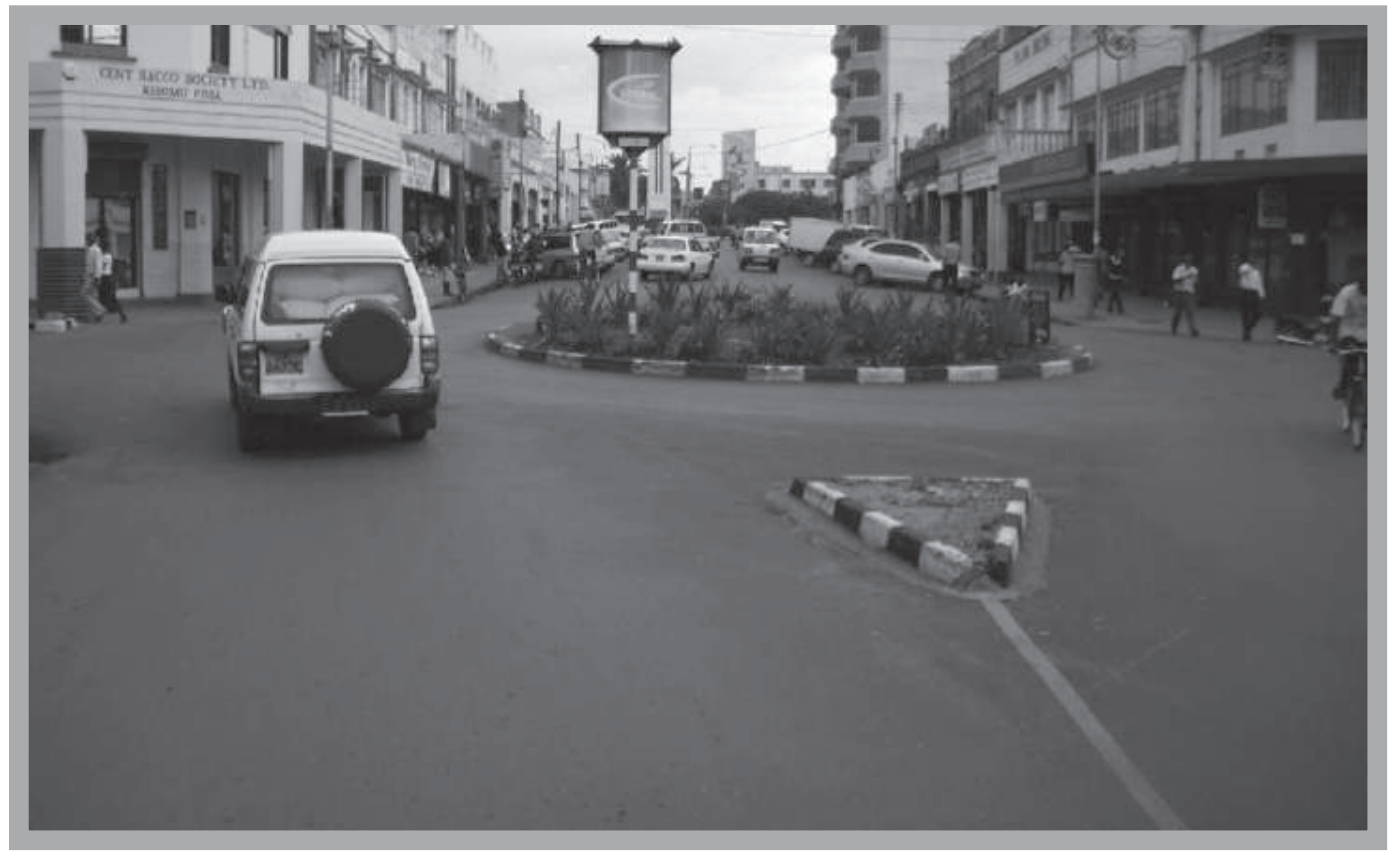

Fig 7: A picture of Asian Business District Showing Well Planned, Modern Environment, Wide roads and Some Landscaping on the Roundabout in Kisumu.

Source: Picture taken by Gordon Omenya (2015).

By 1945, Oginga Odinga alongside other people formed the Bondo Thrift Association which was a fore runner of the Luo Thrift and Trading Corporation (LUTATCO). This association started off by collecting money from members earmarked for business. But also members in distress could borrow from this money. Later, the association began to think concretely about trade. The committee decided to consult some advocates and the Registrar of Societies with a view to soliciting their advice and support on how to launch a trading company. However, during this consultation, the association found itself snubbed and the Asians prevailed. Of the Asian advocates in Kisumu, Odinga had this to say ${ }^{37}$ :

When I sought help in forming a company from Indian lawyers in Kisumu they advised a welfare society; companies would be beyond our knowledge and ability, they said. I went to kisumu to buy books on company law and settled down myself to draft our memorandum and articles of association. We were then ready to decide on a name. We called a meeting for that. Some said it should be called the Bondo Thrift and Trading Corporation. Others were in favour of calling it the Luo Corporation, others the Kenya Thrift and Trading Corporation, and still others the East African Thrift and Trading Corporation

It is, therefore, evident that trade rivalry was very rife in Kisumu. This rivalry depicted the African struggle to dismantle and challenge Asian domination in trade in Kisumu and Nyanza region as a whole. 
The government cotton planting campaign which centred at first on South Kavirondo spread to other districts. This campaign was intermeshed with the administration's zoning policy with the province being divided into three cotton production zones each with its own production targets and seed distribution system. ${ }^{38}$

The government effort to encourage cotton production in Nyanza was, therefore, a precedent to the Afro - Asian interaction in this industry. This interaction would later characterize their relations as Asians went ahead to own cotton stores and ginneries in the areas zoned by the government. These cotton stores and ginneries served as centres of Afro-Asian interaction in the villages of Ndere, and Kibos in Kisumu. Even though cotton growing in Nyanza was a colonial policy, it was facilitated by the Asians and, therefore, it is the Asians who were in direct and frequent contact with Africans in the cotton industry. Afro-Asian interaction in this industry revolved around the Asian ginneries, cotton buying and collection stores and also in their residential areas where they employed Africans as their assistants.

Afro-Asian engagement in the cotton industry did not limit their interactions in trade. The Indian trader played a very important function in the socio-economic life of Africans in Kisumu. The $d u k a$ became a keystone in the country's entire system of distribution, selling goods to Africans and acted as a major outlet for the African agricultural producers. ${ }^{39}$ In their day-to-day activities, Asian racism caused more irritation among Africans. Furedi ${ }^{40}$ quoting Ngugi wa Thiong'o, portrays aspects of this uneasy relationship thus:

The Indian traders were said to be very rich. They too employed some black 'boys' whom they treated as nothing. You could never like the Indians because their customs were funny in a bad way... the Indians were not liked and they abused women using dirty words they had learned in Swahili

Zoning of residential areas according to race did not prevent Afro-Asian interactions. In the Asian households, Asian women prepared chapatis, samosa and bhajias (some variants of wheat baked bread and cakes) which they sold to both Asians and Africans. Some of their dishes were incorporated into the diets of Africans. ${ }^{41}$

At Jamnadas residence in Kisumu, African children would go to the compound to eat a certain fruit which was locally known as jamna coined from the name jamnadas. Henceforth they would say that they were going to kajamna (Jamnadas place) to eat that fruit. This name has stuck with the Africans up to date.

The racial approach which we have noticed in the economic and political fields also applied to the provision of other social services. Education and even sports were organized on strict racial lines, with the Europeans always getting the best services; the Indians, the second

\footnotetext{
${ }^{38}$ G. Kitching, Class and Economic Change in Kenya: The Making of an African Petite Bourgeousie 1905-1970 (London: Yale University Press, 1980) p.74.

${ }^{39}$ I. Kaplan, Area Handbook for Kenya (Washington: Supt. of Docs. , U. S. Govt. Print. Off, 1967) p.533.

${ }^{40}$ F. Furedi, "The Development of Anti-Asian Opinion Among Africans in Nakuru District", African Affairs Vol 73 No 292 (1974):347-360, p.349

${ }^{41}$ Seidenberg, Mercantile Adventures, p.102.
} 
best and the Africans having to do with whatever was left over. ${ }^{42}$ The racial attitudes of providing quality education were also reflected in the field of funding education.

\section{The Political Economy and Afro-Asian Social Engagements during the Decolonization Period 1945-63}

Several organizations such as the Kenya African Union, Central Nyanza Chamber of Commerce, the Ramogi African Welfare Association (RAWA), the Nyanza Soldiers Association, the Luo Union, together with numerous clan and sub-clan welfare organizations were formed to air African grievances and challenge the dominance of Asian traders in the rural areas. Even the defunct Piny Owacho (a local political organization) organization was revived. ${ }^{43}$ These organizations represented voices of negotiation, protest and compromise on the African postcolony. They were initial avenues through which Africans wanted to take over the political and economic power of the postcolony.

The widespread resentment against Asian traders was intensified around the middle of 1948 by what was felt by Africans to be a number of particularly serious malpractices. There was a common view among Africans that Asian traders deliberately hoarded certain commodities and only sold them on the 'black market' for high prices. ${ }^{44}$ Similarly, AfroAsian trade rivalry was also witnessed in the distribution of maize for the Maize and Produce Control Board. In some cases where Africans were reliant on Asian mechanics to repair their vehicles used in the distribution, repairs were badly done or not done at all. ${ }^{45}$ It is, therefore, evident that Asians used some forms of knowledge to undermine and dominate Africans in business.

But even though the Luo Thrift Trading Corporation Limited was a rival and counter corporation to the Asians' dominance in trade in the Nyanza area, the directors of the company still sought some help from the Asians. The Ramogi Press, whose proprietors were members of the Luo Thrift, was relocated from Nairobi to Kisumu in the year 1949. The leaders found it necessary to construct premises for the company to avoid rental increases that would have militated against its progress.

This led to the construction of a new building named the 'AFRIKA HOUSE' owned by the Luo Thrift Corporation. During the opening ceremony of this house in July 1956, the managing director of the corporation, Oginga Odinga applauded the Asians who supplied materials for the construction of the house. These included $\mathrm{M} \backslash \mathrm{s}$ Shamji Harji and Bro limited, M $\backslash$ s E.A Hardwares Limited, M $\backslash$ s Narshi Laxman Bros, M $\backslash$ s Surat Furniture Mart,

\footnotetext{
${ }^{42}$ B.A. Ogot, Kenya under The British, 1895- 1963. In Ogot B.A (ed) Zamani: A survey of East African History (Nairobi: East African Publishing House, 1968) p.276.

${ }^{43}$ B.A. Ogot, British Administration in Central Nyanza District of Kenya, 1900-1960. In Ogot, B.A, (ed.) Reintroducing Man into the African World: Selected Essays 1961-1980 (Kisumu: Anyange Press, 1999) p.46.

${ }^{44}$ Furedi, "The Development of Anti-Asian Opinion", p.351.

${ }^{45}$ H. Fearn, An African Economy: A study of the Economic Development of The Nyanza Province of Kenya 1903-1953 (London: Oxford University Press, 1961) p.190.
} 
$\mathrm{M} \backslash \mathrm{s}$ Dean Brothers and M $\backslash \mathrm{s}$ Teja Singh and Sons, (all Asians) who had been assisting considerably (KNA,PC \NZA $\backslash 3 \backslash 1 \backslash 404,1955-57$ ). This support by Asians depicted the ambivalent nature of subjects within the postcolony. The Luo Thrift Company also built Ramogi House which they leased to an Asian for a period of two years and operated as a cosmopolitan hotel under the business name 'Imperial Hotel' suggesting imperial and colonial aspirations through the Asians (KNA,PC $\backslash N Z A \backslash 4 \backslash 4 \backslash 47,1950$ ). Names such as Afrika House, Ramogi House suggest the aspirations of Africans to maintain their identity and traditional value systems which vastly differed from the Western values.

By 1960, Kisumu had changed from the status of a municipal board to a municipal council (KNA, HT/17/3 Annual Report 1960-65). Henceforth, Asian involvements were felt in the activities of the council. This is exemplified by the participation of Mr M.F Shah, Mr M.P Ondiek (Mayor of Kisumu) and the DC in the activities of the Allocations of Plots (African location) Committee. Their business was to approve African applications for plots within the town for business and residential purposes. Mr. M.F Shah even chaired some sessions of the committee meetings (KNA, DC/KSM/1/30/ 53 1959). Thus a compromise to work together between Asians and Africans together was emerging.

By 1962, the Municipal Council of Kisumu continued to reflect on its dealings during the year that atmosphere of inter-racial harmony, which was experienced in the preceding year. And in July of the same year, councilors Ondiek and Bashir Ud -Deen (an Asian) were re-elected as Mayor and Deputy Mayor respectively for a second term of office. In October, the council obtained added dignity by the elevation of councilors Ondiek, Bashir Ud - Deen, and M.F Shah to an aldermanic bench (members of the council). This event produced pleasurable reactions from councilors of all races (KNA, HT/17/3 AR Central Nyanza District 1962).

By 1963, the general elections were the highlight of the political year. In Nyanza Province, election results for the districts showed that in the House of representative John Odero Soi was elected for Ugenya, Luke Obok for Alego, Tom Okello Odongo for Kisumu Rural, Amir Jamal an Asian for Kisumu Town and Okuto Bala for Nyando (HT/17/3 1963 AR Central Nyanza District 1963). Jamal Amir had just been re-elected Member of Parliament for Kisumu Town. For a second time, three powerful Africans including Walter Fanuel Odede had fallen yet again to this man in the 1963 General elections (Daily Nation 2/2/1990). This means that the interests of the voters on the postcolonial space went beyond racist concerns.

Jamal had a daunting task of convincing majority blacks to vote for him. This is because his opponents, at every political rally emphasized the point that blacks must be led by fellow black people. However, Jamal's argument during his campaigns was different.

He questioned whether the racial issue should strike a valley between the minority Asians and blacks. To him, the two could live together in harmony. He pleaded with the African voters by telling them that, "My dear brothers, my own father came here young and innocent. I was born here. My colour, my race does not make me different. We are all 
brothers. I love you all. I love Kisumu. I know no other home (Daily Nation, 2/2/1990)". During his campaigns in Kisumu, he used both Kiswahili and Dholuo. Even though he knew little Dholuo, he frequently used Kiswahili and sometimes English. Were Olodhe was his interpreter in situations where he could not articulate issues properly in Dholuo (Daily Nation, 2/2/1990).

Jamal was, therefore, able to use captivating words to lure African votes thereby confirming that language is power because words construct reality. ${ }^{46}$ Between 1945 and 1963, Kenya was a society stratified by race. Social status was still largely determined by skin colour and racial group identification. ${ }^{47}$ The racially stratified social structure was particularly evident in the areas of occupation, income and education. Educational inequality formed an obvious and important indicator of the racial structure. Colonial education in Kenya was not only characterized by segregated schools, but also, as in other parts of the world where racial segregation was practiced, inherently unequal. The movement of Asians from the rural areas to Kisumu to seek education marked the period of the development of Asian hostels.

By 1958, the Aga Khan community seriously considered the issue of hostel accommodation for Asian children from remote areas of Nyanza Province because the Aga Khan Mixed Primary School only catered for the education interests of Aga Khan (Ismailia) community (AR 1958). The issue of separate and segregated school system was sustained into the independence era before the African government came up with the policy of integration in public schools. ${ }^{48}$ In general, the Indian community developed its own communal schools with the increasing help of the government. Nevertheless, whatever was taught in the African schools was determined by the missionaries and the government. Culturally, colonialism operated from the racist principle that barbarism pervaded Africa and there was no culture to be salvaged.

The Kisumu Asian Housing Committee catered for the interests of the Asians who were posted to Kisumu to work for the government. The Asian Housing Committee was a purely ad hoc instruments appointed by the PC to assist him in the allocation of houses. Similarly, the Kisumu European Housing Committee was established to help Europeans access good housing (KNA, PC/NZA/2/16/60, 1946-51 10/2/1947). In 1956, the Kisumu Ismailia Housing Society Limited put up sixteen flats for Asians namely, the Aga Khan flats near the new Goan school. The directors of this committee were the Patel Samaj family, whose name was given to the famous Patel flats in Kisumu (KNA, PC/NZA/3/1/404). Later, some Africans within the same economic class started staying in these flats. Nevertheless, segregation policies did not permit Africans to stay with the Asians within their houses except if the Africans were jopidi (baby sitters). Any other person could not be allowed to enter these premises, not even the immediate neighbours. This made the African neighbours

${ }^{46}$ B. Ashcroft B, Griffith G, and Tiffin H, The Empeire Writes Back: Theory and Practice in Postcolonial Literature ( London: Routledge, 1989) p.89.

${ }^{47}$ R. Maxon, Social and Cultural Changes. In Ochieng W. R, and Ogot B.A, (ed.) Decolonisation and Independence in Kenya 1940-93 ( Nairobi: East African Educational Publishers, 1995) p.110.

$194{ }^{48}$ Omenya, The Relations Between Asian and African Communities. 
to develop a negative attitude towards the Asians. ${ }^{49}$

Between 1961 and 1962, the Municipal Council of Kisumu started considering the ways of alleviating the Asian housing problem by negotiating for a site suitable for economy standard Asian housing. This came in handy after the Commissioner of Lands had served a quit notice to a number of families living in temporary wartime dwellings. It was thought that a number of the Asian families would be able to move into the councils' Asian Tenant Purchase houses, which were to be completed in the near future. The council treasurer further proposed that twenty houses similar to those constructed under the existing African Tenant Purchase scheme should be built and made available on rental terms (KNA, $\mathrm{NHC} / 1 / 152,1961)$.

It is clear that housing development was directed along racial lines by the colonial government and this influenced Afro-Asian relations because it reduced interaction only to areas of economic exchange like the trading centres. Africans were given land in the peri-urban areas of Kaloleni, Shaurimoyo and Kibuye. Asians did not move to these areas but concentrated in getting houses within the Central Business District in Kisumu. This has however changed in the recent past with Indians living in peri-urban areas like Kondele, Momboleo and Riat hills in Kisumu. Gripped with the fear of insecurity, which engulfed the entire region towards independence in 1963, there was movement of Asians from the rural areas of Ndere, Yala and Kendu Bay to Kisumu. Some also left Kisumu for Britain. However as Siddiqi ${ }^{50}$ puts it, Africans who were genuinely upset by such developments were the poor, many of whom were employed in Asian businesses and homes. Not only would they be losing their jobs but many had also formed close bonds with their employers.

\section{Post-Independent Afro-Asian Engagements}

The achievement of political independence in 1963 resulted in many changes. Besides bringing vital political decisions under the control of the indigenous Africans, independence also enabled some leaders to make important economic decisions that enhanced the economic standing of the local bourgeoisie. 'Africanization' in particular, was one of the most emotive political slogans in the tumult before independence and President Kenyatta's promise to the people. ${ }^{51}$ Independence did not mark the beginning of a postcolony but it constituted a mere transition from the dominant phase of colonialism to the hegemonic phase of colonialism. The politics of Africanization was simultaneously unifying and fragmenting. Mamdani ${ }^{52}$ argues that its first moment involved the dismantling of racially inherited privilege. The effect was to unify the victims of colonial racism.

The second moment turned around the question of redistribution and divided the same majority, both Asians and Africans, along racial lines that reflected the actual process of redistribution: ethnic and regional.

\footnotetext{
${ }^{49}$ Ibid.

${ }^{50} \mathrm{~J}$. Siddique, Haunts of Uganda 30 years of Old Past (Nairobi: Awaaz, 2004) p.6.

${ }^{51}$ W.Ochieng, Structural and Political changes. In Ogot B. A, (ed.) Decolonisation and Independence in Kenya 1940-93 (Nairobi: East African Educational Publishers, 1995) p.85.

${ }^{52}$ M. Mamdani, Citizen and Subject: Contemporary Africa and the Legacy of Late Colonialism (London: James Curry, 1996) p.20.
} 
Standard notions of the cultural distinctiveness of the Asian were created and consistently applied in a manner that had had serious consequences. ${ }^{53}$ These colonial stereotypical representations of Indians and Africans took root in both communities and continued to order present day constructions of Indians and African identities. ${ }^{54}$ Bharati ${ }^{55}$ has summarized both Asian and African stereotypes thus:

Africans viewed Asians as sneaky, mistrustful; they stick to each other and do not mix with others, they are arrogant, they cheat in business...they are clannish, they monopolize trade within their fold, they are not trustworthy in business nor in social matters.

The Asians on their part accused Africans of being lazy, inefficient, irresponsible, dirty, awkward, primitive and incapable of doing hard work on acquiring skills. These stereotypes gradually developed and came to be regarded as universal characteristic of both Asians and Africans. So Africanization seemed to had borrowed from the pot of stereotypes. The process was to be tackled through the mechanism of legislation and licensing. The first legislation to this effect was the Trade Licencing Act of 1967. This act came into effect on $8^{\text {th }}$ January 1968.

However, the exercise went into full swing in March of the same year. This act excluded non-citizens from trading in rural and non-urban areas and specified a list of goods which were to be restricted to citizen traders only. These included most basic consumer goods, such as maize, rice, sugar, textiles, soap and cement (KNA, HT/17/22 Annual Report 1968). ${ }^{56}$

With the Africanization process in place, many Africans entered into business, but the sector became an active site for Afro-Asian contestation. Africanization, therefore, caused fear among the Asians and some of the Asians started closing down their businesses. This interfered with Afro-Asian economic and social relations in Kisumu.

In Kisumu specifically, the boundary of areas set aside for 'citizens only' were Accra Street, Otieno Oyoo Street, Joshi Avenue, Achieng' Oneko Street and new station road. Others included Kibuye Estate, Mosque Estate, Makasembo, Shaurimoyo, Ondiek, Kaloleni, Lumumba, Nyalenda, Omino Crescent and Pembe Tatu estates surrounded by the Nairobi road, Street, Sailors Close, Karachi Road and Kakamega Road (East Africa Standard October 10, 1969). In the mid-70s, for instance in Kisumu, there were complaints regarding some Africans who secretly resold business premises to Asians. The overall image of Asians was so negative that Kisumu was referred to as the 'Bombay of Kenya' on account of the Indian hold on commerce (East Africa Standard August, 13 and17 1978). In local terms, this reference was considered demeaning.

The public space in Kisumu seemed pluralistic and included both citizens and non-citizens. These were political constructs within the postcolony which gave both Asians and Africans certain identities of inclusion and exclusion. Kisumu was thus a stage on which were

${ }^{53}$ D.Ojwang, "The Bad Baniani Sports Good Shoes; Asian Stereotypes and the Problem of Modernity in East Africa", African Insight Vol 35 No 2 AISA (2005): 4-14, p.5

${ }^{54}$ S. Rampersad, 'Indian -African Relations in the English - Speaking Caribean' (Nairobi: Awaaz, 2007) p. 33.

${ }^{55}$ A. Bharati, The Asians in East Africa. Jayhind and Uhuru (Chicago: Nelson Hall Company, 1972) p.170.

$196{ }^{56}$ Ochieng, "Structural and Political changes", p.85. 
played out the wider problems of subjection and its corollary, discipline. ${ }^{57}$ In this case, Asians appeared to be the subject. But at the same time, there was evidence of a mimicry of the colonial style of rule by Africans.

The 'Citizens only area' was thus a space and stage where economic negotiations and contestations were fulfilled. Asians loathed the Africanization policy because it destabilized their businesses. Individual traders like Habib Okore (Asian) went back to Uganda where he operated a bakery and a dairy farm. Tahidin, the owner of Kendu ginnery sold it to Rachuonyo Cooperative Union and relocated permanently to Kisumu. It is evident again that there is shift from individual ownership of ginneries by Asians to a mass kind of ownership in terms of cooperative unions.

By 1975, another Asian industrial undertaking, the Kisumu Cotton Mills (KICOMI) came into the scene as a textile industry (Weekly Review, 21/1/1983). Contrary to the ginning factories in Ndere, Yala and Kendu Bay, this was a more advanced industry where Asians were manufacturing ready-made clothes, bed sheets, and curtains for both local and international markets. The Asian owners employed a number of African workers whom they trained on how to operate weaving machines. This was done under the supervision of the Asians.

\section{Political Transformations and Afro-Asian Interactions in the Kenyatta, Moi and Kibaki Eras}

Some of the political developments at the national level affected and shaped what was happening at the local level as far as Afro-Asian political relations in Nyanza Province were concerned. By 1965, Pio Gama Pinto's critical attitude and closeness to Kenya's first vice president Jaramogi Oginga Odinga brought him into conflict with powerful elements within the ruling party. On $24^{\text {th }}$ February 1965 , Pinto was shot dead in the driveway of his home. ${ }^{58}$ This occurrence sent a shocking wave to the Asians whose fear increased in urban centres and rural areas where they lived. This affected Afro-Asian political relations in these areas as Pinto's death was perceived by Asians as racially and politically motivated.

By 1966, the radicals led by Oginga Odinga, Bildad Kaggia and Achieng' Oneko broke away from KANU and formed the Kenya People's Union (KPU). However, the most important point to note here is that some Asians who were close associates of Oginga Odinga such as Pranlel Sheth who resided in Kisumu were deported to India. No reasons were given for the action against these individuals, except for a statement put out by the official Kenya News Agency that ${ }^{59}$ :

\footnotetext{
${ }^{57}$ A. Mbembe, On the Postcolony (Berkeley: University of California Press, 2001) p.103.

${ }^{58}$ Zarina, I am A Kenyan, p.22.

${ }^{59}$ P.M. Rattansi, Rebel With a Cause (Nairobi: Awaaz, 2004) p. 24.
} 
The six Asians deported had shown themselves by act and speech to be disloyal towards Kenya, joining it with a warning that those who chose to take up Kenya citizenship must identify themselves with the country in all its aspects and not engage in 'subversive activities against the state or any other activities'. The newspaper also printed a summary of a broadcast the previous day in which the official Voice of Kenya declared that the entire Asian community in Kenya today 'stands indicted by the activities of some of its members'.

Intimidation was a feature of the postcolony in its formal disposition. It is still the practice of the postcolony in its informal dispensation. Africans were simply replicating what whites did. Thus the struggle by Odinga, Kaggia and Pinto was still the struggle for decolonization against an informal postcolony still operating under British colonial rules.

In August 1966, president Kenyatta himself took up the theme when addressing the KANU branch at Nyali Beach Hotel in Mombasa, by sternly urging and warning the 'immigrant communities' to either identify themselves with the aspirations of the people of Kenya, or pack up and leave. ${ }^{60}$

These statements were not favourable in harnessing Afro-Asian relations as they showed the ambivalent nature of the state towards Asians after Independence. In fact, it heightened tension and suspicion which already existed in the run-up towards independence. Further warnings were repeated in 1967. These statements destabilized Asians already living in the rural areas of Nyanza leading to the withdrawal of many more from these places. Even though the Asians viewed these statements as racist diatribes, they also demonstrated that with the onset of independence, nothing much had changed in terms of the government structure. It is only the leadership which changed. As Fanon ${ }^{61}$ says, decolonization is quite simply the replacing of a certain 'species' of men by another 'species' of men. Such warnings laid the foundation upon which Afro-Asian hostilities were laid during the Kenyatta era. However, these warnings did not affect Asian participation in politics in Kisumu District.

By 1967, the Asians who were in politics as members of the Kisumu council were Abdul E. Dahya who was the deputy mayor, M.F Shah, and Y.J. Farjallah (KNA,DC/KSM/17/40, 1964, KNA, HT/17/19, 1967). When the 1969 elections came, Jamal Amir who had served as the Member of Parliament for Kisumu after the 1963 election never defended his parliamentary seat which fell to the first female mayor, Mrs Grace Onyango (Daily Nation, 2/2/1990). Abdul Dahya did not quit politics but was not successful in his quest to secure a civic seat in the subsequent elections. Despite some racist anti-Asian rhetoric by a section of Kenyan African politicians, physical molestation was, however, rare. ${ }^{62}$

During the Moi era, Asians continued to extend their domination not only in the retail and distributive sectors, but also in practically every aspect of the economy (Finance, May 1997:7). Their investment thrived in manufacturing and the service sector (hotels, banks, wholesale trade and construction). This was driven by local demand originating from

${ }^{60}$ Ibid, p.25

${ }^{61}$ F. Fanon, The Wretched of the Earth (Middlesex: Penguin Books, 1967) p.27.

${ }^{62} \mathrm{M}$. Chege, EAST vs EAST: The role of Minorities in Business, East Asia and East Africa Compared (Nairobi: Awaaz, 198 2004) p. 17. 
the cash crop boom from African smallholdings in the 1960 s to the $1980 \mathrm{~s}^{63}$. The Asian community reasserted themselves by investing in Nyanza and more so in Kisumu in areas such as construction, real estate and outlets including supermarkets, banks, hotels, and the manufacturing sector. Nearly all the local entrepreneurs within the town belonged to the Asian community. ${ }^{64}$ Apart from textiles, metal works, engineering, weaving, spinning and soap making which were of Asian interest among the first large-scale manufacturing to be established in Nyanza Province, many more Asian industrial interests continued to emerge. These companies could be classified according to the products that they produced for instance flour, bread, concrete pipes, soft drinks, mattresses, matches, soap, fishnets, sweets, shipbuilding, general engineering, fish filleting, processing and freezing. ${ }^{65}$ These Asian manufacturing companies supported a majority of Africans who could not get jobs in the civil service. Indeed these industrial ventures represented the Asians' contribution towards the economy of Kisumu district.

Afro-Asian relations in the Moi era were unique in the sense that many Africans had acquired education and professional skills compared to the colonial and Kenyatta periods when most of them were employed as domestic servants and unskilled labourers. This educational background made Africans to be employed in Asian firms as professionals such as doctors, engineers, mechanics, teachers and accountants among others. Afro-Asian relations within these categories of people were, therefore, different from the Afro-Asian relations that existed between the Asian dukawallahs and the local Africans in the village. This is because the Asians recognised the professionalism of the people they employed. In most cases, relations between African professionals and their Asian employers in places such as Jalaram Hospital, United Millers Company and Kisumu Senior Academy, Southern Credit Bank among others in Kisumu, were often more or less equal since African professionals knew their rights and would always negotiate for pay commensurate to the services offered and their qualification. ${ }^{66}$ This period also witnessed the emergence of a new generation of Indian immigrants commonly referred to as comet or rockets.

In 1987, tension and suspicion between Asians and Africans in Kisumu went up. This tension arose over the issue of entry into Simba Club (Sikh Union). This was a 'members only' club owned by Asians, but was used as a checkpoint during the 1987 Safari Rally competitions. As the rallying cars started arriving at this checkpoint, the management of the club decided to allow Asians only into the club to watch the rallying cars while African entry was restricted. This was evidently an act of discrimination and a clear show of racial prejudice which offended the Africans. The result of this was the revival of conflict between Africans and Asians. It also brought into focus the question of Asian citizenship in the minds of Africans in Kisumu. This scenario of strained relations was filled with emotional undercurrents that made the area volatile. ${ }^{67}$

\footnotetext{
${ }^{63}$ Ibid.

${ }^{64}$ W.H.A Olima, The Land Use Planning in Provincial Towns of Kenya: A case Study of Kisumu and Eldoret Town (Dr Ing. Dissertation Degree of Dortmund University, 1993); Anyumba, Kisumu Town.

${ }^{65}$ M. Opondo, The Spatio-Structural Characteristic of Small Scale Industries in Kisumu Municpality (M.A thesis, Kenyatta University, 1989) p.51

${ }^{66}$ Omenya, The Relations Between Asian and African Communities.

${ }^{67}$ Ibid.
} 
By 1988, there was competition between the Africans who were selling second-hand clothes (mitumba) and the Indian cloth manufacturers who felt that this business was a threat to the textile industry Kisumu Cotton Mills (KICOMI). The mitumba business within the postcolony symbolized the nature of unequal economic life of the postcolony. Therefore, there is a struggle among different categories of people which makes this chaotic space to be negotiated through all means. Through political connections, Asians prevailed upon the government to ban the sale of second-hand clothes in Kisumu and in the entire country (The Weekly Review, 1987). This did not auger well with the local business people and caused some tension between those Asians who engaged in the textile industry and the African businessmen and women as well as the general African consumers in Kisumu who relied so much on second-hand clothes which they considered cheap as compared to the KICOMI products. ${ }^{68}$

In the 1990s in Kisumu, the number of supermarkets and other businesses owned by Asians increased remarkably and these included Ebrahims, Yatin, Sai and Ukwala supermarkets. Some of these supermarkets emerged from what was initially the wholesale trade which Asians upgraded and expanded to supermarket status. Other businesses which Asians engaged in were social pubs like Monami, Club Kiboko and the film industry since they operated the Tivoli Cinema and Nyanza cinema respectively.

But it is also at these business avenues that one could clearly see the glaring economic differences between Asians and Africans. In many ways these economic disparities were a critical feature of the postcolonial space. In these places, some close Afro-Asian relations also emerged. Afro-Asian relations, therefore, depended on the trust and what one had in common with the other. If there was nothing in common to share, then one could not freely relate or interact with Asians and vice versa. These interactions were mostly at the level of business. ${ }^{69}$

Similarly, there were situations when Asians entered into business relationship with Africans at a higher level. For instance in 1991, there was a joint business venture in Kisumu between Asian and African personalities like J. Nyaseme, Mr J. Shah, the late Bishop H. Okullu and the late Hon H. Omino who jointly run the Victoria Finance and Lake Credit Finance (The Weekly Review, 8/3/1991). This partnership therefore gave these organisations an ownership identity that was neither Asian nor African. Such kind of business relationships ensured growth of the business sector in Kisumu as well as enhancing Afro-Asian relations.

With their diversity in businesses, such as hardware, construction and engineering and general shops, Asians met the demands of Africans by either employing them or providing essential services to the people around the town. Asians like Teja Singh made clothes for both Asians and Africans. Others like Lal sold tea leaves to the Africans from his grocery in town. 
With all these developments, anti-Asian resentment did not go missing. Local African leaders in Kisumu such as Dennis Akumu, a former trade unionist, supported anti-Asian sentiments by claiming that Asians had 'exploited' Africans for far too long and should thus be expelled from towns such as Kisumu where they dominated trade and commerce (The Weekly Review May 24, 1996:17/18). Most of the Africans working for Asians bought this idea and were just waiting for the moment when they would be told that Asians were leaving so that they could take over their businesses. It is from such tensions both psychic and political that a strategy of subversion emerged. ${ }^{70}$ Seemingly, such sentiments affected Afro-Asian relations in the sense that Asians developed fear which further isolated them from the Africans. As Bindra ${ }^{71}$ argues, 'the more we are resented, the more we isolate ourselves, the more we isolate ourselves the more we are resented'. As resentment grew, Asians continued to isolate themselves from the African community into the "islands of safety and comfort'. This 'island mentality' according to Bindra ${ }^{72}$ was the community's greatest mistake. This was because it affected their relations with Africans since they could not interact freely in social places. Such was the kind of ambivalent relations that characterised Afro-Asian interaction in Kisumu.

A number of top Asian businessmen developed some personal relationship with government personalities at the national level. Such kind of political relationship affected Afro-Asian relations at the local level in terms of business. For instance, the Hindocha, Somaia, Hayer Bishan Singh families appeared to have had powerful business connections with top officials in the government, a connection which they used to win government tenders and sometimes cover up several underhand economic deals in conjunction with government officials (The Weekly Review, 13 1996:17). Because of their closeness to the Moi regime, they were able to manipulate the provincial labour and police offices in order to safeguard and protect their business interests. This was an image which Asians could not shake off with ease. ${ }^{73}$ In the year 2000s and subsequently, Asians, with the help of Shakeel Shabir, the former Kisumu mayor and the current Member of Parliament for Kisumu Town East having won the 2007 Parliamentary election, voted for the National Rainbow Coalition (NARC) government which was popular in Nyanza Province. In 2013, general elections Shakeel managed to defend his seat on an ODM ticket thereby ending racism and clannism that dominated the constituency politics for decades. Within the medical circles, Asian doctors were able to dismantle the racial barrier in order to discharge their duties to Africans. But also, Africans willingly sought medical attention from Asian doctors, some of whom became family doctors for certain African families. ${ }^{74}$ But also doctor Shabir, an Asian managed to train some African women whom he employed in his clinic as midwives. A good example was a lady (deceased) popularly known as Mama Leah who later owned the Nyawita Maternity and Nursing Home in Kisumu after working for doctor Shabir for several years. ${ }^{75}$

\footnotetext{
${ }^{70}$ Bhabha, The Location of Culture, p.89

${ }^{71}$ S. Bindra, We are Kenya Damu (Nairobi: Awaaz, 2005) p.2.

${ }^{72}$ Ibid, p. 6

${ }^{73}$ Ibid.

${ }^{74}$ Omenya, The Relations Between Asian and African Communities.

${ }^{75}$ Ibid.
} 
Asians continued to enjoy economic dominance during the Kibaki era. More so, after the post-election violence of 2007/8 where one of the Asian supermarkets (Formatt) was looted and accidentally burnt down. Asian entrepreneurs and businessmen have come back to buy premises which were hitherto owned by Africans from central province (members of the Kikuyu community). These include the former Kimwa Grand Hotel in Kisumu part of which is now operating as a supermarket, Tumaini supermarket formerly located at a Timber yard initially owned by a kikuyu from central province. It is therefore suffice to state that interethnic political rivalry between Africans during the Kibaki era enhanced Afro-Asian relationship in Kisumu. This is evident by an emergence of Asians operating businesses in places like Kondele which was an epicentre of the post election violence in 2008. This is quite ambivalent owing to the past business rivalry between Asians and Africans. Nevertheless, a bitter rivalry was witnessed in the year 2014 when the Sikh Asian community decided to mark their centenary in Kisumu by building a sculpture within the town centre (Figure 8). A number of African residents resented about this sculpture arguing that it was a symbol of Asian continued economic dominance over Africans in Kisumu (Figure 9). Others argued that it was a symbol of an idol, which was contrary to their Christian religion. Nevertheless, these contestations are some of the things, which have shaped the landscape of Kisumu and have also characterized the postcolonial social and economic spaces in Kisumu.

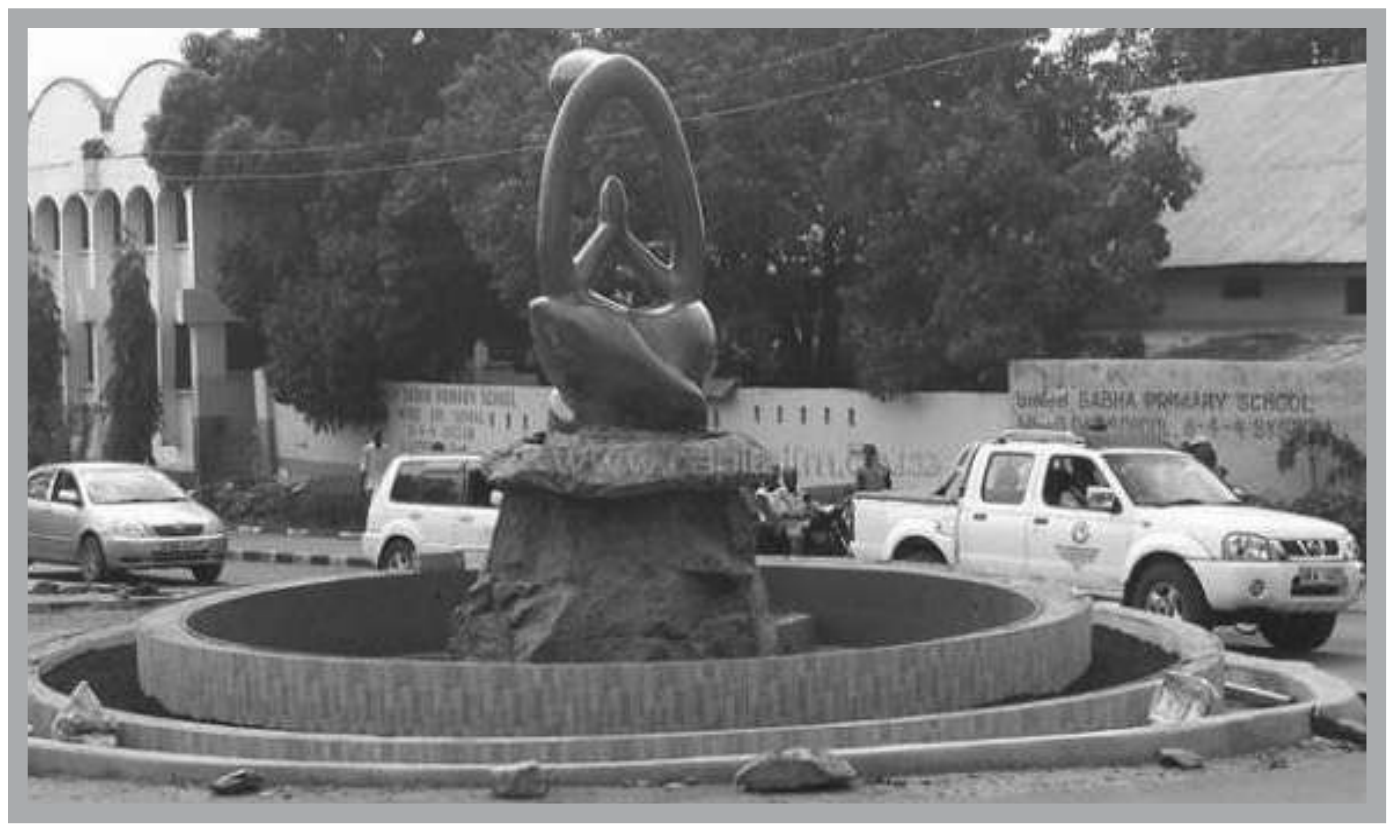

Fig 8: A Picture of a Sculpture Erected by the Sikh community To Mark their 100 Years in Kisumu Town Source: Daily Nation, 6th February, 2014. 


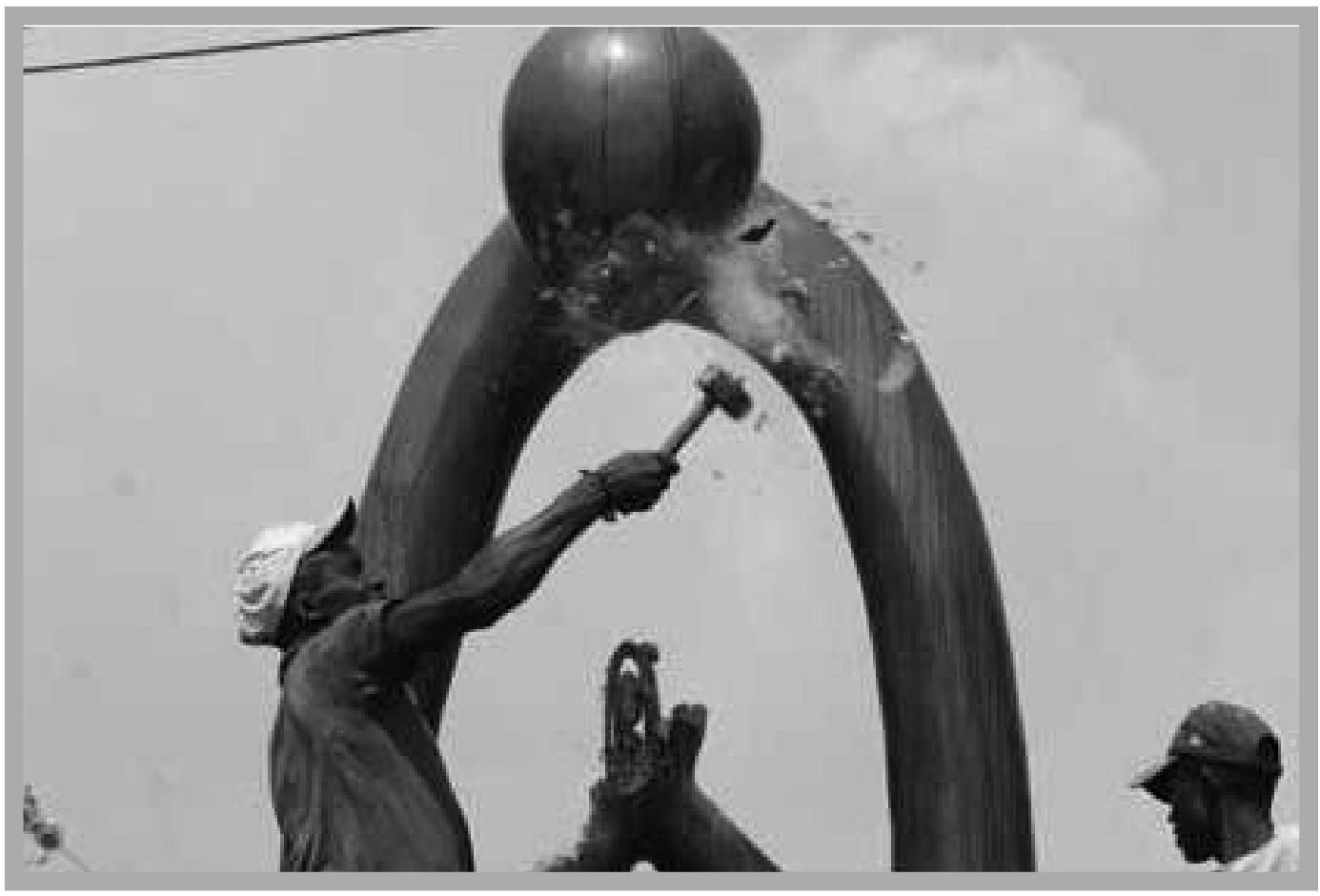

Fig 9. Demonstrators attack a sculpture erected by the Sikh community in Kisumu town Source: Daily Nation, 6th February 2014.

\section{Conclusion}

This article has given an historical account of the Afro-Asian socio-economic and political engagements in Kisumu district and how the Asian Influence and changed the urban landscape of Kisumu. It has mapped out that economic engagements revolved majorly around trade and commerce but also some limited social relations were witnessed in residential areas. Asians played a key role in imparting various skills to Africans, in car repair, construction of houses and also in the medical circles. However, conflict and contestations also arose within the economic space of Kisumu. This was a sign of a bid by Africans to assert themselves within the economic space of Kisumu. Similarly, it is also evident that the built form of Kisumu and the landscapes was majorly influenced by the Asian presence in the area. Some of the Asian classical houses and architectural designs are a living testimony to the global connection between Kisumu and the Indian-subcontinent. Their visual culture and African cultural values also permeated and were borrowed by each of the two communities. In the later years after independence, the postcolonial government with its policy of Africanisation affected Afro-Asian socio-economic relations. The Asians therefore developed strategies of survival in these uncertain situations by aligning themselves with the powers that would be depending on their circumstances. After the election of 2007 which was marred by violence, it emerged that Asians resorted to buying and leasing business premises in Kisumu that were hitherto rented out to Africans from central Kenya, a situation which demonstrates that deep rooted ethnic political rivalry allowed for interracial relations to thrive among the Luo owners of some of the properties. 


\section{Archival Sources}

KNA, PC/NZA/1/4 Annual Report 1908/9

KNA/PC/NZA Annual Report 1928

$\mathrm{KNA} / \mathrm{PC}$ ?NZA/2/16/60

KNA/PC/NZA/1/16 Annual Report 1920-21

KNA/PC/NZA/3/15/142 1931-50

$\mathrm{KNA} / \mathrm{PC} / \mathrm{NZA} / 3 / 1 / 404$ 1955-51

$\mathrm{KNA} / \mathrm{PC} / \mathrm{NZA} / 4 / 4 / 47$

KNA/HT/17/3 Annual Report 1960-65

KNA/DC/KSM/1/30/53 1959

$\mathrm{KNA} / \mathrm{DC} / \mathrm{KSM} / 17 / 40$

KNA/NHC/1/152 1962

KNA/HT/17/22 Annual Report

KNA, HT/17/19 Kisumu District Annual Report 1967

MCK (Municipality Council of Kisumu) Annual Report 1979

Annual Report 1913/14

Annual Report, AR 1979

\section{Magazines}

East African Standard, 10/10/69, 13/08/1978

Daily Nation 2/02/1990, 9/1/70, 25/9/95

Daily Nation, $6^{\text {th }}$ February, 2014

East African Standard, 10/10/69, 13/08/1978

Finance May 13-26 1997

WR Weekly Review, 21//1983 , 8/3/1991, 1987, 1996 


\section{References}

Anyumba, G. Kisumu Town: History of The Built Form, Planning and Environment 18901990. Ph.D. Thesis, Moi University, 1995.

Ashcroft, B., Griffith, G. and Tiffin H. The Empeire Writes Back: Theory and Practice in Postcolonial Literature. London: Routledge, 1989.

Atieno, Odhiambo E. Siasa: Politics and Nationalism in East Africa 1905 - 1939. Nairobi: Kenya Literature Bureau, 1981.

Bhabha, H. The Location of Culture. London: Routledge, 1994.

Bharati, A. The Asians in East Africa. Jayhind and Uhuru. Chicago: Nelson Hall Company, 1972.

Bindra, S. We are Kenya Damu. Nairobi: Awaaz, 2005.

Chege, M. EAST vs EAST: The role of Minorities in Business, East Asia and East Africa Compared. Nairobi: Awaaz, 2004.

Dubey, A. India and Indian Diaspora in Africa: Diversity and Challenges. In Indian Diaspora in Africa: A Comparative Perspective, ed. Dubey A, New Delhi: MD Publication PVT Ltd, 2010.

Fanon, F. The Wretched of the Earth. Middlesex: Penguin Books, 1967.

Fearn, H. An African Economy: A study of the Economic Development of The Nyanza Province of Kenya 1903-1953. London: Oxford University Press, 1961.

Furedi, F. "The Development of Anti-Asian Opinion Among Africans in Nakuru District", African Affairs Vol 73 No 292 (1974): 347-360.

Herzig, P. South Asians in Kenya: Gender, Generation and Changing Identities in Diaspora. Munster: LIT Verlag/Transaction publishers, 2006.

Gayer, L. Diaspora Indo-Pakistanaise et régulation de la conflictualité Londres et a Paris DEA dissertation. Paris: Institute d'études politiques 1998.

Kaplan, I. Area Handbook for Kenya. Washington: Supt. of Docs. , U. S. Govt. Print. Off, 1967.

Kitching, G. Class and Economic Change in Kenya: The Making of an African Petite Bourgeousie 1905-1970. London: Yale University Press, 1980.

Lemmen, L. Technology Assessment for Projects in Developing Economies: Sugarcane Industry in Western Kenya as a Case Study. Unpublished PhD Dissertation, Eindhoven University of Technology, 1987.

Mamdani, M. Citizen and Subject: Contemporary Africa and the Legacy of Late Colonialism. London: James Curry, 1996.

Mangat, J. A. History of Asians in East Africa c 1886 - 1945. New York: Oxford University Press, 1969. 
Mangat, S. J. The Immigrant Communities (2): The Asians. In History of East Africa Vol III, ed. Low, D.A and Smith A. London: Clarendon Press, 1976.

Maxon, R. Social and Cultural Changes. In Decolonisation and Independence in Kenya 1940-93, eds. Ochieng W. R, and Ogot B.A. Nairobi: East African Educational Publishers, 1995.

Mbembe, A. On the Postcolony. Berkeley: University of California Press, 2001.

Mickleburg, A. Publishing in the $21^{\text {st }}$ Century: Reflections for the South Asian Diaspora and East African Project- A virtual, Electronic, Historical Dictionary. In Confronting Twenty First Century Challenges, eds. Makana R., and Rutanga M. Kampala: Faculty of Social Sciences Makerere University, 2004.

Memon, P. "Colonial Marketing, and Urban Development in the African Reserves". Journal of Eastern Africa Research and Development, Vol 6, No.2 (1976).

Moliner, C. « Frères ennemis? Relations between Panjabi Sikhs and Muslims in the Diaspora ». South Asia Multidisciplinary Academic Journal [Online], 1 | 2007, Online since 14 October 2007, connection on 18 July 2016.

URL : http://samaj.revues.org/135 ; DOI : 10.4000/samaj.135

Morris, J. and Winchester, S. Stones of Europe, The Buildings of the Raj. Oxford: Oxford University Press, 1986.

Ndege, P. Internal Trade in Kenya 1895-1963. In An Economic History of Kenya, eds. Ochieng W., and Maxon R. Nairobi: East African Educational Publishers, 1992.

Obudho, R. Periodic Markets Urbanisation and Regional Planning: A Case Study from Western Kenya. London: Greenwood Press, 1976.

Ochieng', W. An Outline History of Nyanza Up to 1914. Nairobi: East African Literature Bureau, 1974.

Structural and Political changes. In Decolonisation and Independence in Kenya 1940-93, eds. Ogot B. A. Nairobi: East African Educational Publishers, 1995.

Odinga, O. Not Yet Uhuru. London: Heinemann, 1967.

Ogot, B. A. Kenya under The British, 1895- 1963. In Zamani: A survey of East African History, eds. Ogot B.A. Nairobi: East African Publishing House, 1968.

British Administration in Central Nyanza District of Kenya, 1900-1960. In Reintroducing Man into the African World: Selected Essays 1961-1980, eds. Ogot, B.A. Kisumu: Anyange Press, 1999.

My Footprints on The Sands of Time: An Autobiography. Kisumu: Anyange Press Limited, 2003.

Ojwang, D. "The Bad Baniani Sports Good Shoes; Asian Stereotypes and the Problem of Modernity in East Africa". African Insight Vol 35 No 2 AISA, 2005.

Olima, W.H.A. The Land Use Planning in Provincial Towns of Kenya: A case Study of 206 Kisumu and Eldoret Town. Dr. Ing. Dissertation Degree of Dortmund University, 1993. 
Omenya, G. The Relations Between Asian and African Communities of Kenya' Nyanza Province 1901-2002. M.A Thesis, Kenyatta University, 2010. The Relations Between Asian and African Communities: A Comparative Study of Western and Nyanza Provinces of Kenya, 1900-2002. PhD Thesis l'Universite de Pau, France, 2015.

Opondo, M. The Spatio-Structural Characteristic of Small Scale Industries in Kisumu Municpality. M.A thesis, Kenyatta University, 1989.

Rampersad, S. Indian -African Relations in the English - Speaking Caribean. Nairobi: Awaaz, 2007.

Rattansi, P.M. Rebel With a Cause. Nairobi: Awaaz, 2004.

Salvadori, C. We Came in Dhows. Vol 1-3, Nairobi: Paperchase Limited, 1996.

Seidenberg, A. Mercantile Adventures: The World of East African Asians 1750-1985. New Delhi: New Age International (P) Limited Publishers, 1996.

Sharma, J.C. The Indian Communities in Overseas Territories of France: Problems of Identity and Culture. In Diversities in The Indian Diaspora: Nature, Implications, Response, ed. Jayaram. New Delhi: Oxford University Press, 2011.

Siddique, J. Haunts of Uganda 30 years of Old Past. Nairobi: Awaaz, 2004.

Tandon, Y. The Future of the Asians in East Africa. London: Rex Collings Ltd, 1973.

Zarina, P. I am A Kenyan South Asian. Nairobi: Awaaz, 2004. 